\title{
Perancangan Logo dan Slogan Kabupaten Trenggalek Sebagai Media City Branding
}

\author{
Bramantya Yoga Widyaswara, Berto Mulia Wibawa, dan Muhammad Saiful Hakim \\ Departemen Manajemen Bisnis, Fakultas Bisnis dan Manajemen Teknologi, \\ Institut Teknologi Sepuluh Nopember (ITS) \\ e-mail:muh.saiful.hakim@gmail.com
}

\begin{abstract}
Abstrak-Kabupaten Trenggalek mempunyai potensi alam dan budaya yang dapat menarik wisatawan, namun belum memiliki citra yang baik dibandingkan dengan kota lain. Tujuan penelitian ini, yaitu mengidentifikasi dan merancang logo dan slogan yang efektif untuk meningkatkan citra Kabupaten Trenggalek. Proses perancangan elemen city branding dimulai dengan identifikasi karakteristik Kabupaten Trenggalek melalui in depth interview kepada tokoh masyarakat, perancangan elemen city branding, serta konfirmasi dan validasi desain elemen city branding kepada keyplayer Kabupaten Trenggalek melalui Focus Group Discussion (FGD). Hasil dari FGD, yaitu terpilih logo alternatif dua dan "Southern Paradise" sebagai slogan Kabupaten Trenggalek.
\end{abstract}

Kata Kunci-City Branding, Kabupaten Trenggalek, Pariwisata.

\section{PENDAHULUAN}

$\mathrm{P}$ ERKEMBANGAN arus globalisasi mempengaruhi persaingan antar kota dalam menarik investor [1]. Setiap kota berusaha untuk meraih awareness dalam berkompetisi untuk menjadi kota yang paling menarik bagi pengunjung internasional [2].

Brand dari sebuah kota dianggap menjadi aset penting bagi pembangunan perkotaan, diferensiasi, peningkatan positioning, dan peningkatan pangsa pasar [3]. Istilah branding pada suatu tempat mendorong munculnya konsep city branding, City branding berbicara tentang identitas khusus suatu kota yang berbeda dengan kota lain sehingga dapat mudah diidentifikasi [4]. Berbagai manfaat akan didapatkan dengan menerapkan strategi city branding diantaranya awareness, reputasi dan persepsi yang baik mengenai destinasi wisata, selain itu city branding juga dapat meningkatkan iklim investasi, serta peningkatan kunjungan wisatawan. Seiring dengan pemberlakuan otonomi daerah, setiap daerah di Indonesia berusaha untuk menunjukkan diferensiasi dengan kota lain [5]. Seperti yang dikembangkan di Surabaya dengan memanfaatkan kampung yang memproduksi berbagai minuman herbal dan dijadikan sebagai tujuan wisata [6]. Di Indonesia potensi alam dan budaya lokal yang khas sangatlah melimpah, akan tetapi potensi ini belum optimal mendatangkan wisatawan karena belum adanya city branding yang menunjang. Salah satu wilayah yang belum mengoptimalkan potensinya melalui city branding adalah Kabupaten Trenggalek.

Kabupaten Trenggalek merupakan salah satu Kabupaten di Provinsi Jawa Timur yang terletak di pesisir pantai selatan. Kabupaten Trenggalek memiliki banyak potensi seperti potensi wisata, potensi budaya, potensi perkebunan, potensi perikanan, potensi tambang, potensi kuliner dan masih banyak lagi. Kekayaan alam dan budaya lokal di Kabupaten Trenggalek belum bisa menarik wisatawan untuk datang ke daerah ini, terbukti dari jumlah wisatawan hanya 586,260 orang pada tahun 2015 [7]. Nilai tersebut masih jauh jika dibandingkan dengan kabupaten sekitarnya. Hal tersebut karena Kabupaten Trenggalek belum mampu menonjolkan ciri khas yang dimiliki untuk menarik wisatawan. Jika Kabupaten Trenggalek melakukan branding, maka Pendapatan Asli Daerah (PAD) Kabupaten Trenggalek dapat meningkat. PAD Kabupaten Trenggalek pada tahun 2015 hanya Rp. 155,25 milyar rupiah [8]. Oleh karena itu untuk meningkatkan citra pariwisata Kabupaten Trenggalek ditingkat Internasional diperlukan perancangan elemen city branding yang menarik sesuai dengan potensi kekayaan alam dan budaya lokal di Kabupaten Trenggalek sehingga dapat meningkatkan Pendapatan Asli Daerah (PAD) Kabupaten Trenggalek. Penelitian ini berfokus pada perancangan elemen city branding yang sesuai dengan karakteristik Kabupaten Trenggalek.

\section{TINJAUAN PUSTAKA}

\section{A. City Branding}

City branding adalah metode yang digunakan dalam memasarkan suatu kota. Kota membutuhkan citra dan reputasi yang kuat dan berbeda seperti halnya produk atau jasa. Reputasi dan citra ini sangat penting demi mengatasi persaingan kota dalam memperebutkan sumber daya ekonomi di tingkat lokal, regional, nasional dan global [9]. City branding merupakan strategi kota untuk membuat kesan yang kuat kepada target pasar mereka, seperti layaknya kesan yang dibangun pada sebuah produk atau jasa, sehingga negara dan daerah tersebut dapat dikenal secara luas diseluruh dunia [10].

\section{B. Brand Elements}

Brand elements atau brand identities merupakan pembeda dengan produk lain atau perusahaan lain. Elemen utama yang membedakan antara satu perusahaan dangan perusahaan lain adalah nama merek, logo, simbol, karakter, kemasan, jingle, dan juga slogan. Brand elements yang baik akan meningkatkan brand awareness pada konsumen, karena tolok ukur sebuah brand dari sebuah organisasi atau produk dilihat dari brand elements-nya [11].

\section{METODOLOGI PENELITIAN}

\section{A. Desain Penelitian}

Pada penelitian ini penulis menggunakan jenis desain penelitian deskriptif observational. Penelitian deskriptif merupakan jenis penelitian yang dilakukan dengan mengungkap fakta yang terjadi waktu sekarang, sedangkan penelitian observational menekan pada penelitian yang 
dihasilkan dari observasi, tanpa memberikan intervensi pada Tabel 1

Identifikasi Karakteristik Kabupaten Trenggalek

\begin{tabular}{|c|c|c|c|c|c|c|}
\hline \multirow[b]{2}{*}{$\begin{array}{l}\text { Karakteri } \\
\text { stik } \\
\text { Kabupate } \\
\text { n } \\
\text { Trenggal } \\
\text { ek }\end{array}$} & \multicolumn{6}{|c|}{ Karakteristik Kabupaten Trenggalek } \\
\hline & $\begin{array}{l}\text { Agoes } \\
\text { Sarund } \\
\text { eng } \\
\text { (R1) }\end{array}$ & $\begin{array}{l}\text { Wieto } \\
\text { no } \\
\text { (R2) }\end{array}$ & $\begin{array}{c}\text { Dyah } \\
\text { Retnowati } \\
\text { Ardhaning } \\
\text { rum S.E. } \\
\text { (R3) }\end{array}$ & $\begin{array}{c}\text { Aji } \\
\text { Sulisti } \\
\text { ono } \\
\text { (R4) }\end{array}$ & $\begin{array}{c}\text { Dima } \\
\text { s } \\
\text { Bella } \\
\text { Prada } \\
\text { na } \\
\text { (R5) } \\
\end{array}$ & $\begin{array}{l}\text { Pujiriy } \\
\text { anti } \\
\text { (R6) }\end{array}$ \\
\hline Pantai & $\sqrt{ }$ & $\sqrt{ }$ & $\sqrt{ }$ & $\sqrt{ }$ & $\sqrt{ }$ & $\sqrt{ }$ \\
\hline $\begin{array}{l}\text { Pegunun } \\
\text { gan }\end{array}$ & $\sqrt{ }$ & $\sqrt{ }$ & $\sqrt{ }$ & $\sqrt{ }$ & - & - \\
\hline $\begin{array}{l}\text { Turongo } \\
\text { yakso }\end{array}$ & $\sqrt{ }$ & - & $\sqrt{ }$ & $\sqrt{ }$ & - & - \\
\hline Tiban & - & - & - & $\sqrt{ }$ & - & - \\
\hline Durian & - & - & - & $\sqrt{ }$ & - & $\sqrt{ }$ \\
\hline Salak & - & - & - & $\sqrt{ }$ & - & - \\
\hline $\begin{array}{l}\text { Alen- } \\
\text { alen }\end{array}$ & - & - & - & $\sqrt{ }$ & - & - \\
\hline $\begin{array}{l}\text { Guo } \\
\text { lowo }\end{array}$ & - & - & - & - & $\sqrt{ }$ & - \\
\hline $\begin{array}{l}\text { Larung } \\
\text { sembony } \\
\text { o }\end{array}$ & - & - & - & - & - & $\sqrt{ }$ \\
\hline
\end{tabular}

\section{B. Proses Perancangan Elemen City Branding}

Proses perancangan elemen city branding dimulai dengan identifikasi karakteristik Kabupaten Trenggalek melalui in depth interview kepada tokoh masyarakat dari berbagai profesi. Tahap selanjutnya, yaitu penetapan konsep desain yang disesuaikan dengan gaya hidup masyarakat Indonesia saat ini. Setelah menentukan konsep desain selanjutnya merancangan desain elemen city branding. Kemudian desain elemen city branding dikonfirmasi dan divalidasi kepada keyplayer Kabupaten Trenggalek melalui FGD, serta merevisi hasil masukan yang diperoleh dari tahap FGD.

\section{IV.PEMBAHASAN}

\section{A. Identifikasi Karakteristik Kabupaten Trenggalek}

Tahap ini bertujuan untuk mengidentifikasi karakteristik yang dimiliki oleh Kabupaten Trenggalek berdasarkan sudut pandang dari tokoh dengan berbagai profesi. Tahap ini dilakukan malalui in depth interview kepada enam tokoh masyarakat Kabupaten Trenggalek dengan latar belakang yang berbeda, yaitu Agoes Sarundeng sebagai budayawan (R1), Wietono sebagai pelukis (R2), Dyah Retnowati Ardhaningrum S.E. sebagai pemerintah Dinas Pariwisata Kabupaten Trenggalek (R3), Aji Sulistiono sebagai wartawan (R4), dan dua orang warga yaitu Dimas Bella Pradana dan Pujiriyanti (R5, R6). Hasil identifikasi karakteristik Kabupaten Trenggalek disajikan pada Tabel 1.

Berdasarkan Tabel 1 dapat diketahui bahwa karakteristik Kabupaten Trenggalek menurut enam responden yang terdiri atas budayawan, seniman, pemerintah, wartawan, dan warga adalah pantai, dataran tinggi, dan turonggo yakso karena ketiga karakteristik tersebut mempunyai skoring paling tinggi daripada karakteristik lainnya.

Sepanjang wilayah selatan Kabupaten Trenggalek berbatasan langsung dengan Samudra Indonesia sehingga Kabupaten Trenggalek mempunyai garis pantai dan pesisir yang membentang di seluruh wilayah selatan. Pantai di Kabupaten Trenggalek juga mempunyai keindahan yang khas dan tidak pernah ada di pantai lainnya. Pegunungan variabel yang akan diteliti.

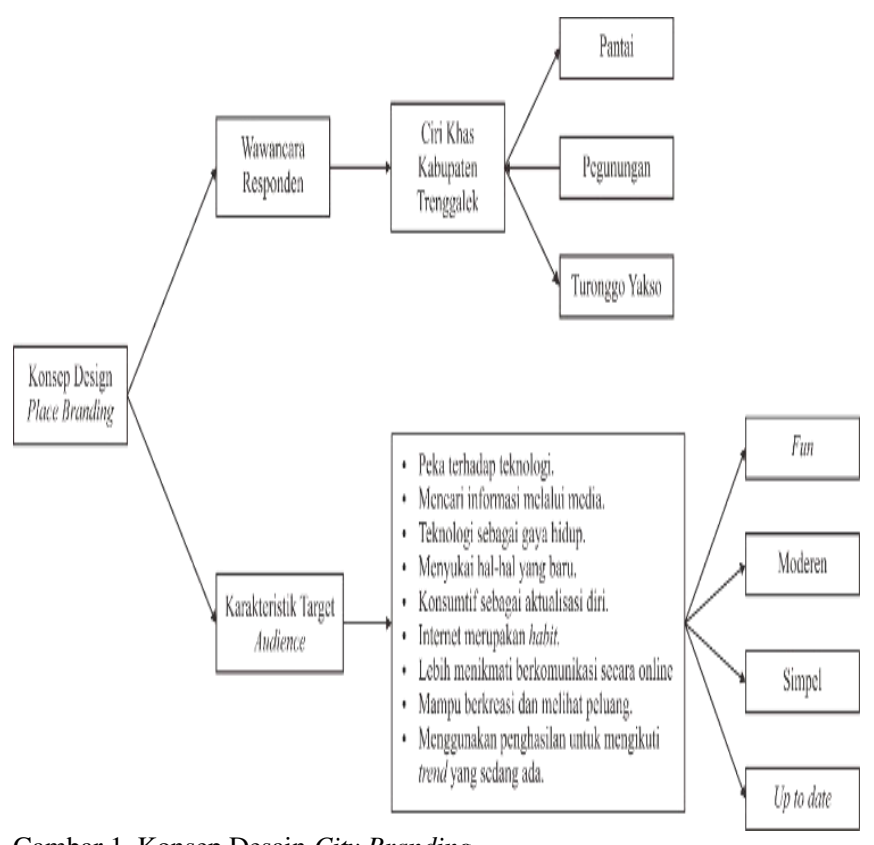

Gambar 1. Konsep Desain City Branding.

sesuai untuk menjadi karakteristik Kabupaten Trenggalek karena lebih dari 50\% wilayah Kabupaten Trenggalek adalah dataran tinggi atau pegunungan dengan pusat kotanya juga dikelilingi oleh pegunungan. Kontur pegunungan ini menyebabkan Kabupaten Trenggalek mempunyai hawa yang sejuk sehingga cocok untuk kegiatan pertanian dan perkebunan. Tarian Turonggo Yakso cocok untuk dijadikan karakteristik Kabupaten Trenggalek karen tarian ini merupakan tarian diciptakan oleh masyarakat yang berlatar belakang cerita rakyat Trenggalek. Disamping itu, tarian ini sering ditampilkan dalam acara-acara resmi serta telah mewakili Kabupaten Trenggalek di pentas kesenian nasional. Karakteristik Kabupaten Trenggalek yang telah didapat dari hasil skoring kemudian digunakan untuk merancang elemen city branding.

\section{B. Rancangan Desain Elemen Branding}

Konsep desain dari elemen branding Kabupaten Trenggalek diperoleh dari karakteristik Kabupaten Trenggalek yang telah ditetapkan pada tahap sebelumnya. Berdsarkan tiga karakteristik Kabupaten Trenggalek, yaitu pantai, dataran tinggi dan turonggo yakso akan didistribusikan ke dalam desain elemen branding. Konsep desain juga dipengaruhi dengan target audience atau pasar yang akan disasar. Perilaku masyarakat Indonesia pada umumnya memiliki interest pada trend, gaya hidup, pekerja keras, inovatif, dan ketenaran [12]. Dari karakteristik tersebut dapat disimpulkan bahwa target konsumen memiliki selera yang fun, modern, simpel dan up to date. Konsep tersebut selanjutnya dijadikan dasar penentuan konsep desain city branding.

Berdasarkan hasil wawancara dengan para tokoh masyarakat yang ada di Kabupaten Trenggalek, pemilihan warna tidak ada pengkhususan. Konsep pewarnaan yang digagas banyak menggunakan campuran warna primer yang kontras sehingga dapat menimbulkan efek psikologis maupun optikal yang menarik. Perpaduan warna merupakan unsur penting yang sangat dibutuhkan untuk menciptakan visualisasi yang menarik, sehinggai perpaduan warna tidak ditampilkan dengan sembarangan. Untuk bahasa yang digunakan, menggunakan bahasa persuasif yang menarik, 


\section{Trenggalek}

Gambar 2. Logo Terpilih.

adapun beberapa menggunakan bahasa Inggris sebagian

Sesuai dengan konsep desain logo bertema fun, moderen, dan up to date dengan menampilkan pesona keindahan Kabupaten Trenggalek yang memiliki aspek dominan pantai. Logo terdiri dari dua bagian, yaitu bagian teks nama identitas dan simbol yang melambangkan karakteristik Kabupaten Trenggalek. Pada bagian simbol terdiri atas empat unsur utama, yaitu pantai, awan senja, perahu layar, dan destination point.

Logo menggunakan tiga pilihan warna pokok, yaitu warna oranye dan biru. Dari ketiga pilihan warna pokok di perluas menjadi beberapa warna variasi, biru muda dan biru tua. Warna oranye merupakan warna hangat dan ramah yang membuat orang merasa nyaman. Oranye adalah hasil peleburan merah dan kuning, sehingga efek yang di hasilkan masih tetap sama, yaitu kuat dan hangat, karena sebab itulah warna ini paling banyak di pakai untuk menarik perhatian orang. Warna biru memiliki sifat yang menyegarkan, selain itu warna biru sering di anggap sebagai warna yang melambangkan kepercayaan dan trustfulness.

Jenis font yang digunakan pada logo memiliki tipe san serif. San serif berarti huruf yang tidak memiliki sirip pada ujung hurufnya sehingga memiliki ketebalan huruf yang sama atau hampir sama. Pememilihan tipe font san serif menimbulan kesan yang moderen, kontemporer dan efisien pada sebuah logo. Font yang digunakan pada ini menggunakan font "Harabara" pada tulisan Trenggalek dan font "Lato" pada tulisan slogan. Harabara memiliki kesan yang moderen tatapi tidak kaku dan cenderung memiliki kesan fun. Font Lato pada tulisan slogan memiliki kesan yang profesional sehingga perpaduan huruf harabara dan lato sangatlah cocok.

Kabupaten Trenggalek tidak memiliki ciri khas khusus yang sangat menonjol dalam aspek pertanian, perikanan, perkebunan, sosial, budaya, pariwisata dan lain sebagainya. Walaupun Kabupaten Trenggalek tidak memiliki ciri khas khusus yang sangat menonjol, namun Kabupaten Trenggalek memiliki potensi yang besar. Hampir disegala aspek Kabupaten Trenggalek mempunya potensi yang besar, baik dalam aspek pertanian, perikanan, perkebunan, sosial, budaya, pariwisata dan lain sebagainya walau tidak menonjol. Untuk itu Kabupaten Trenggalek tidak bisa menetapkan disalah satu aspek untuk dijadikan identitas Kabupaten, sehingga perlu identitas yang lebih umum namun berkarakter. Atas dasar itu peneliti merancang slogan untuk Kabupaten Trenggalek yaitu "Southern Paradise" yang memiliki arti surga yang terletak di selatan. Alasan menggunakan Southern karena Kabupaten Trenggalek terletak di bagian selatan provinsi Jawa Timur yang berbatasan langsung dengan pesisir selatan. Dari letak geografis Kabupaten Trenggalek ini gagasan menggunakan kata Southern. Selain itu selatan dalam kepercayaan masyarakat jawa kuno ditunggu oleh Batara Brahma yang elemen seperti slogan dan kalimat ajakan. Untuk bahasa yang digunakan pada deskripsi penjelasan menggunakan bahasa Indonesia yang menarik.

Setelah melalui proses penentuan konsep selanjutnya proses pembuatan desain alternatif, dan divalidasikan kepada keyplayer Kabupaten Trenggalek melalui FGD, maka logo yang terpilih adalah logo dari alternatif kedua seperti divisualisasikan pada gambar 2.

merupakan dewa dengan gelar dewa kebijaksanaan. Kata Paradise yang berarti surga didapat dari keindahan alam yang dimiliki Kabupaten Trenggalek. Keindahan bagai di surga kesan pertama orang yang menikmati keindahan alam yang dimiliki Kabupaten Trenggalek.

\section{KESIMPULAN}

Terdapat tiga karakteristik Kabupaten Trenggalek yang menonjol untuk diangkat sebagai ciri khas Kabupaten Trenggalek, yaitu pantai, dataran tinggi dan turonggo yakso.

Konsep desain yang dirancang oleh peneliti menggunakan unsur karakteristik utama Kabupaten Trenggalek, selain itu konsep desain juga dipengaruhi dengan target audience atau pasar yang akan disasar yang memiliki selera fun, modern, simple, dan up to date. Rancangan desain dikonfirmasi dan divalidasi kepada keyplayer Kabupaten Trenggalek melalui Focus Group Discussion (FGD) untuk menentukan logo Kabupaten Trenggalek dan dipilih yaitu logo alternatif kedua dan "Southern Paradise" sebagai slogan city branding Kabupaten Trenggalek.

\section{DAFTAR PUSTAKA}

[1] J. Pfefferkorn, "Exploring City Branding and the Importance of Brand Image," J. Mark., vol. 2, no. 12, pp. 98-125, 2005.

[2] Tayebi, "How to design the brand pf contemporary city," $J$ Brand Manag., vol. III, no. 6, pp. 9-22, 2006.

[3] G. J. Ashworth and M. Kavaratzis, "Beyond the logo: brand management for cities," J. Brand Manag., vol. 13, no. 4, pp. 20 31, 2009.

[4] G. Ashworth, "The instruments of place branding: How is it done?," Eur. Spat. Res. policy, vol. 5, no. 4, pp. 9-22, 2009

[5] R. H. Magnadi and F. Indriani, "Peran Perguruan Tinggi dalam Membangun 'City Branding' yang Berkelanjutan: Sebuah Upaya untuk Mendorong Pertumbuhan Perekonomian Daerah," in Prosiding SNaPP: Sosial, Ekonomi, dan Humaniora, 2011, p 281.

[6] B. Wibawa and et al, "Business Model and Value Proposition Design for The Establishment of The Herbal Tourism Village in Surabaya," in Internasional Conference on Innovation in Business and Strategy, 2016.

[7] Badan Pusat Statistik, "Jumlah Pengunjung Obyek Wisata Di Kabupaten Trenggalek," 2015.

[8] Badan Pusat Statistik, "Realisasi Penerimaan Dan Daerah Kabupaten Trenggalek," 2017.

[9] M. R. Yananda and U. Salamah, Branding Tempat (Membangun Kota, Kabupaten, dan Provinsi Berbasis Identitas). Jakarta: Makna Informasi, 2014.

[10] G. J. Ashworth and M. Kavaratzis, Towards effective Place Brand Management: BrandingEuropean Cities and Regions. Cheltenham: Edward Elgar, 2010.

[11] K. Keller, Strategic Brand Management, Building, Measuring and Managing. Edinburgh Gate: Perason, 2013.

[12] B. T. Indrojarwo, Sabar, and E. Zulaikha, "Visual Design Study of City Branding of Surabaya as a National Creative Industry Center with MDS Method," J. City Brand., vol. 1, no. 2, pp. 1 21,2010 . 